International Journal of Applied Linguistics \& English Literature

ISSN 2200-3592 (Print), ISSN 2200-3452 (Online)

Vol. 1 No. 5; September 2012 [Special Issue on General Linguistics]

\title{
Perspectives on Oral Communication Skills for Engineers in Engineering Profession of Pakistan
}

\author{
Inayatullah Kakepoto (Corresponding Author) \\ Universiti Teknologi Malaysia, Faculty of Education, Johor Bahru, Johor, 81310 Malaysia \\ Quaid-e-Awam University of Engineering Science \& Technology Nawabshah 67480 (Sind) Pakistan \\ E-mail: inayat_kakepoto@yahoo.com \\ Noor Abidah Mohd Omar, PhD \\ Universiti Teknologi Malaysia, Language Academy, Johor Bahru, Johor, 81310 Malaysia \\ E-mail: m-abidah@utm.my \\ Yusuf Boon, PhD \\ Universiti Teknologi Malaysia, Faculty of Education, Johor Bahru, Johor, 81310 Malaysia \\ E-mail: yusofboon@yahoo.com.my \\ S M Zafar Iqbal \\ Universiti Teknologi Malaysia, Faculty of Electrical Engineering, Johor Bahru, Johor, 81310 Malaysia
}

Received: 30-07- 2012

Accepted: 15-08- 2012

Published: 03-09- 2012

doi:10.7575/ijalel.v.1n.5p.176

URL: http://dx.doi.org/10.7575/ijalel.v.1n.5p.176

\begin{abstract}
Communication plays paramount role for engineers to perform workplace jobs effectively in this modern age of industrialization. The purpose of this research paper was to determine importance of oral communication for engineers at workplace. Thirty engineers from 2 engineering organizations participated in this study. Purposive sampling method was used for data collection since respondents were drawn on specific criteria of engineers with minimum 5 years work experience. Quantitative survey based on questionnaire survey was used for data collection purpose. Data were analyzed using Statistical Package for Social Sciences (SPSS 15.0). The results of the study indicated that oral communication skills such as oral presentation, participation in meetings, conversation, discussion, and negotiation skill play significant role for engineers at workplace. Thus, quantitative data analysis results indicate that oral communication skills play significant role for engineers to perform workplace jobs efficiently in this competitive work environment of organizations. However, the results of this study are consistent with other literature review findings on importance of oral communication skills for engineers at workplace.
\end{abstract}

Keywords: Communication skills, Oral communication skills, engineers, engineering workplace

\section{Introduction}

Globalization has brought dramatic changes in workplace especially in engineering profession during the last three decades. Due to blessing of globalization all major engineering organizations conduct business all over the world and earn various financial benefits for industrialists. Engineering graduates should understand that globalization is not a bubble that will burst within days but it is a phenomenon that will stay longer in coming days and will demand more skilled workforce equipped with technical and non technical skills to increase workplace productivity of organizations. Additionally, due to increasing role of globalization in business arena many new fields have emerged for instance engineering education and business communication. Many researchers are busy to conduct surveys to provide appropriate feedback to engineering universities to prepare better human capital for workplace. Thus, these global changes demand from engineering graduates to acquire broad array of skills such as communication and oral communication skills to be fit in this competitive work environment of organizations. Engineering graduates have to communicate with people at workplace such as workers, customers, managers, employers and other stakeholders within and outside organizations.

Communication, oral communication, soft skills, generic skills and employability skills are interchangeable 
International Journal of Applied Linguistics \& English Literature

ISSN 2200-3592 (Print), ISSN 2200-3452 (Online)

Vol. 1 No. 5; September 2012 [Special Issue on General Linguistics]

words in literature review that indicate that modern engineering graduates should be proficient in these skills if they want to be successful at workplace in order to perform workplace jobs successfully. No doubt, these skills assist engineering graduates to obtain a job and thereby excel in job promotion ladder at workplace. Moreover, industry recognizes importance of communication skills for engineers (Dannels, 2003; Korte et al., 2008) because engineers equipped with effective communication skills contribute to promote business of organizations. Communication functions as soul blood of any organization and engineering organizations heavily rely on effective communication skills of its employees. Tilli and Trevelyan (2008) noted that engineers $60 \%$ of time spend in communicating with people at workplace. Thus, these increased communications demand effective oral communication skills of engineering graduates to perform workplace jobs successfully and productively.

It is a general perception at workplace that engineers equipped with effective oral communication skills augment workplace productivity of organizations. Thus, management of organizations usually gives important assignments to those engineers who tended to be equipped with effective oral communication skills. As a result, engineers equipped with effective oral communication skills are considered productive engineers for organizations from employer perspective point of view. In certain instances employers show concern that they do not find engineers to perform such roles which include collaboration and coordination with other organizations. Conversely, engineering graduates equipped with poor oral communication skills bring poor financial benefits for organizations. Thus, employers usually consider them as burden on organizations. Engineering graduates equipped with poor oral communication skills tend to fail to persuade industrialists to buy their company products. Marketing has become an important aspect of modern workplace and employers look for those engineering graduates who can play multiple roles to promote business of organizations.

Technical skills were main skills to obtain and retain a job at workplace but latest developments have changed scenario of world of work (James and James, 2004). Employers consider communication and oral communication skills as significant skills for engineering graduates who are aspirant to join workplace. Clear and concise communication is fundamental for success in global business environment (Jaderstrom et al., 2008) and the ability to communicate effectively makes one graduate distinct from others. Employers look for those engineering graduates who can communicate well with multiple stakeholders on the job. Thus, communication skills have become important for engineering graduates to obtain a job in local as well as global organizations. Moreover, employers never compromise on effective communication skills (Hoggatt, 2003) of engineering graduates because their major objective is to run business of organizations productively and earn profits.

James Lippe (2005) surveyed college graduates and results of this study indicated that communication skills are important skills for workplace jobs. Sutton (2002) noted that right now if you have two candidates for a job and both are technically sound but one job candidate possesses better communication skills. The candidate that possesses better communication skills will get the job against the candidate who lacks in this skill. This clearly indicates that modern engineering graduates should possess effective communication skills since they have to communicate with colleagues, supervisors, managers and other people from different organizations. Additionally, skills are essential for job success and students equipped with effective communication skills surpass others to obtain a job in the workplace (Employers Value Communication and Interpersonal Abilities, 2004).

Oral communication skills at workplace include presentation skill, participation in meetings, conversation, discussion, and negotiation. Engineers perform oral presentations on regular basis to keep management of the organization well informed about progress of work projects and barriers that obstruct progress of that work. Research has found that engineers usually perform oral presentations at workplace (Hafizoah Kassim et al., 2010), therefore they should be proficient in oral presentations (Bhattacharyya et al., 2009). A study was conducted on importance of oral presentation for engineers at workplace. The results of this study revealed that $78 \%$ engineers were required to demonstrate oral presentations at workplace (Keane, 1999). Meeting is an important aspect of modern workplace and it assists employers to formulate strategies to run business of organizations smoothly and increase workplace productivity of organizations. Thus, all major organizations conduct daily meetings to discuss problems that affect workplace productivity. Bargiela et al. (1997) illustrated that meetings provide platform for promoting organizational work. Attending meetings, presenting information and promoting company's image all are communication ways (Lehman and DuFrene, 2008), that lead towards well being of an organization.

Conversation is an informal source of communication between workers, supervisors, managers and engineers at workplace. Like meetings it does not require any special setting such as conference room or seminar hall. Thus, it is a common mode of communication between employees at workplace. Communication is the means for 
International Journal of Applied Linguistics \& English Literature

ISSN 2200-3592 (Print), ISSN 2200-3452 (Online)

Vol. 1 No. 5; September 2012 [Special Issue on General Linguistics]

achieving occupational activity, enabling employees to acquire new skills which facilitate solutions of problems (Mellinger, 1992). Conversations develop better work relationship (Woodilla, 1998) among employees. On the other hand, discussion is an important aspect of workplace communication. It provides an opportunity to gain work related knowledge from senior engineers. Simultaneously, it generates an atmosphere of trust and confidence between upper and lower management that impacts on health of organizations in terms of profits.

Moreover, negotiation is an important aspect of workplace communication and it involves communication with multiple people from within and outside organizations. Managers approximately spend $20 \%$ of their time negotiating and perhaps that $20 \%$ of time impact remaining $80 \%$ of their activities at workplace (Baron, 1989). Carvalho Fernando et al. (2001) conducted a study on importance of communication skills for successful negotiation in complex business environments. These researchers investigated Portuguese managers and executives from 500 largest Portuguese companies in the year 2001. Results of this study indicated that Portuguese managers and executives revealed that the ability to communicate effectively is very important in negotiations.

Van Horn (1995) surveyed employees in New Jersey in the United States. Results of this survey reported that oral communication was rated by employers as vital but, it is an area in which graduates severely lack. In another study Crosling and Ward (2002) surveyed workplace communication skills for business graduates in Monash University. The findings of the survey indicated that $84 \%$ employer respondents without specifying forms of oral communication indicated that oral communication usually occurs at workplace. Later, Gray (2009) investigated importance of oral communication skills for accountancy graduates in New Zealand. The findings of this study indicated that $91 \%$ of respondents considered oral communication skills as 'very important' at workplace. Moreover, Arn et al. (2010) surveyed employers on workplace communication skills. The results of this survey indicated although electronic communications were important work skills but oral communication skills were deemed more important that employees should possess for workplace jobs. In a recent study Freihat Saleh et al. (2012) conducted study on "The Picture of Workplace Oral Communication Skills for ESP Jordanian Business Graduate Employees". The results of this study indicated that $84 \%$ respondents agreed that oral communication often occurs at workplace.

It is worth mentioning here although these studies were conducted in business context but they all indicate importance of oral communication for graduates at workplace. This research is significant because it reveals information regarding importance of oral communication for engineering graduates at workplace. The findings of this study would contribute to existing body of communication literature on workplace oral communication skills that would guide engineering graduates to acquire effective specific oral communication skills prior to joining workplace if they want to be part of modern workplace environment that involves communications with multiple stakeholders at national and international level.

\section{Methodology}

The research adopted quantitative methods based on questionnaire survey. Thirty engineers from 2 engineering organizations participated in this study. Purposive sampling method was employed for data collection purpose since respondents were drawn on specific criteria of 5 years work experience. Moreover, the rationale for selection of engineers with five years work experience was based on the understanding that these engineers would be better able to provide appropriate feedback regarding the importance of oral communication skills for engineers at workplace. Purposive sampling is a non probabilistic sampling method that is used for specific purpose (Singleton \& Straits, 2005).

The questionnaire used for this study contained two parts. First part included demographic information asking about gender, qualification, age, field of discipline, nature of job and work experience. Twenty eight male engineers and 2 female engineers participated in this study. All 30 engineers possessed the degree bachelor of engineering (B.E.). Nine engineers ranged between the age 25-30 years, thirteen 30-35 and eight 40-45 years old. Six were mechanical engineers, 21 electrical engineers, 2 electronic engineers and 1 chemical engineer. All 30 respondents were full time engineers and twenty one possessed $(5-10)$ years work experience, two (10-15), one (15-20) three (20-25) and three $(25-30)$ years.

The second part of this questionnaire contained statements relating to importance of oral communication for engineers at workplace. A 5 point likert scale ranging $1=$ strongly disagree, $2=$ disagree, $3=$ neutral, $4=$ agree, and $5=$ strongly agree. 
International Journal of Applied Linguistics \& English Literature

ISSN 2200-3592 (Print), ISSN 2200-3452 (Online)

Vol. 1 No. 5; September 2012 [Special Issue on General Linguistics]

\section{Data Analysis}

Data were analyzed quantitatively using Statistical package for Social Sciences (SPSS15.0) to draw percentages for agreement and disagreement level of respondents for the variables included in the questionnaire.

\section{Findings}

The findings of the study have been categorized into five headings such as oral presentation, participation in meetings, conversation, discussion, and, negotiation skill for engineers at workplace.

\subsection{Oral Presentation}

The results for oral presentation indicated that 5\% engineers strongly disagreed, $6 \%$ disagreed, $11 \%$ responded neutral, 39\% agreed, and $39 \%$ strongly agreed that oral presentation plays paramount role for engineers at workplace.

\section{Oral Presentation}

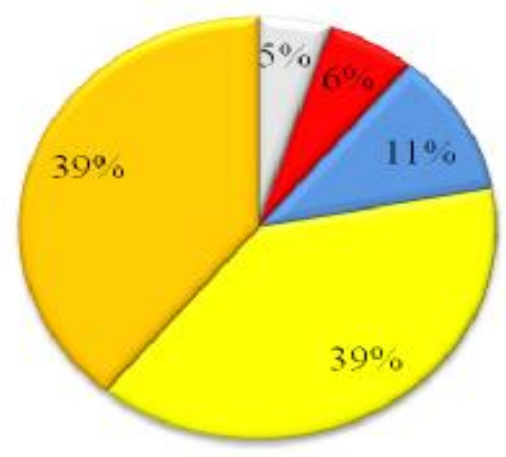

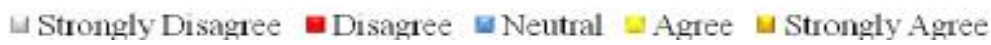

Figure 1 shows that 39\% engineers agreed and 39\% strongly agreed that oral presentation is a required skill for engineers at workplace.

\subsection{Participation in Meetings}

The results for participation in meetings indicated that $1 \%$ engineers strongly disagreed, $5 \%$ disagreed, $10 \%$ responded neutral, 54\% agreed, and 30\% strongly agreed that oral communication plays important role to participate in meetings at workplace.

\section{Participation in Meetings}

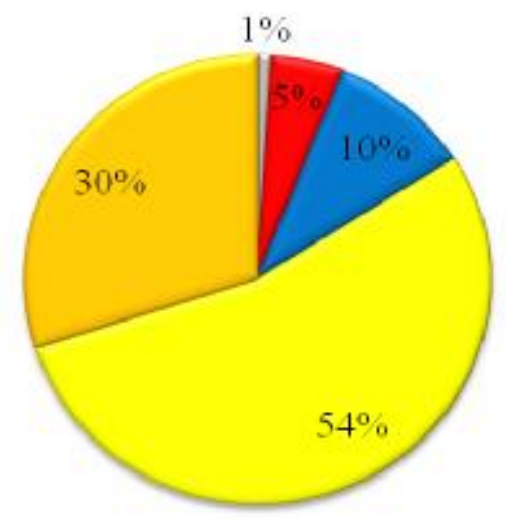

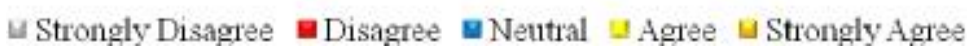




\section{International Journal of Applied Linguistics \& English Literature \\ ISSN 2200-3592 (Print), ISSN 2200-3452 (Online)}

Vol. 1 No. 5; September 2012 [Special Issue on General Linguistics]

Figure 2 shows that 54\% engineers agreed and 30\% strongly agreed that oral communication is an important factor to discuss work related matters during meetings.

\subsection{Conversation}

The results for conversation indicated that $1 \%$ engineers strongly disagreed, $6 \%$ disagreed, $12 \%$ responded neutral, $52 \%$ agreed, and $29 \%$ strongly agreed that oral communication plays important for taking part in conversations at workplace.

\section{Conversation}

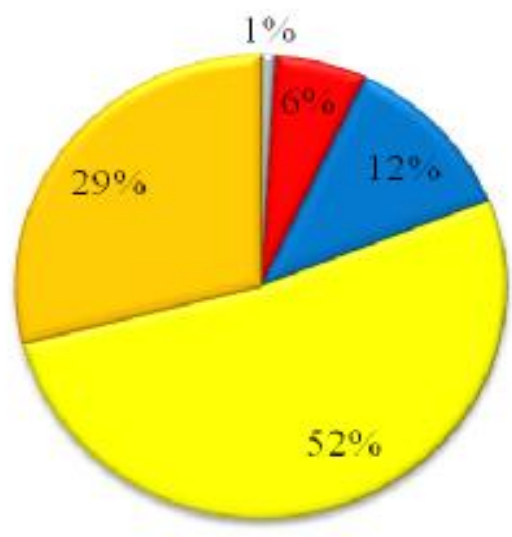

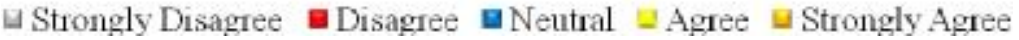

Figure 3 shows that 52\% engineers agreed and 29\% strongly agreed that workplace conversations develop better work relationship among engineers at workplace.

\subsection{Discussion}

The results for discussion indicated that $1 \%$ engineers strongly disagreed, $9 \%$ disagreed, $6 \%$ responded neutral, $50 \%$ agreed, and $34 \%$ strongly agreed that oral communication plays important role for engineers to discuss work related problems with senior engineers at workplace.

\section{Discussion}

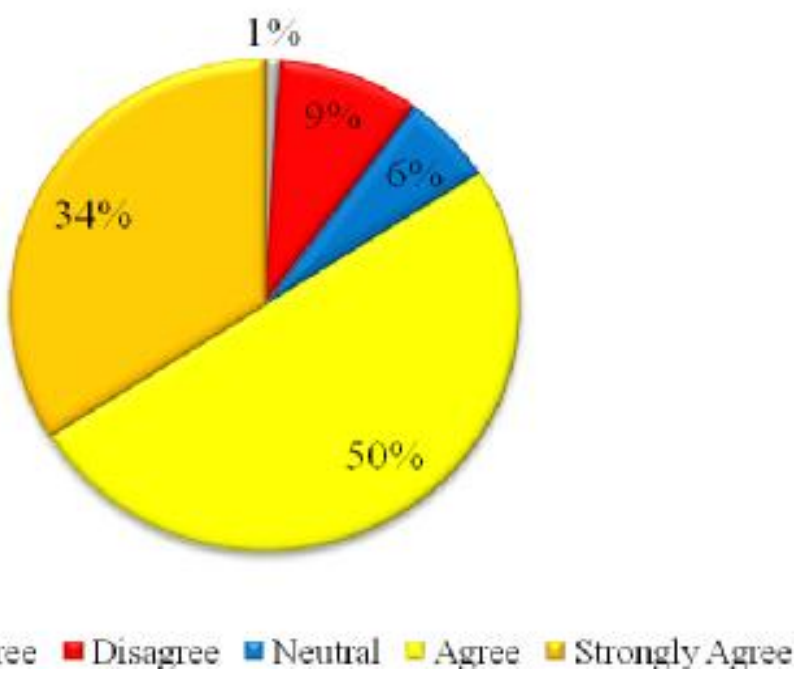

Figure 4 shows that 50\% engineers agreed and 34\% strongly agreed that workplace discussions promote better work environment of organizations. 
International Journal of Applied Linguistics \& English Literature

ISSN 2200-3592 (Print), ISSN 2200-3452 (Online)

Vol. 1 No. 5; September 2012 [Special Issue on General Linguistics]

\subsection{Negotiation}

The results for negotiation indicated that $1 \%$ engineers strongly disagreed, $7 \%$ disagreed, $9 \%$ responded neutral, $51 \%$ agreed, and $32 \%$ strongly agreed that oral communication plays important role for taking part in workplace negotiations.

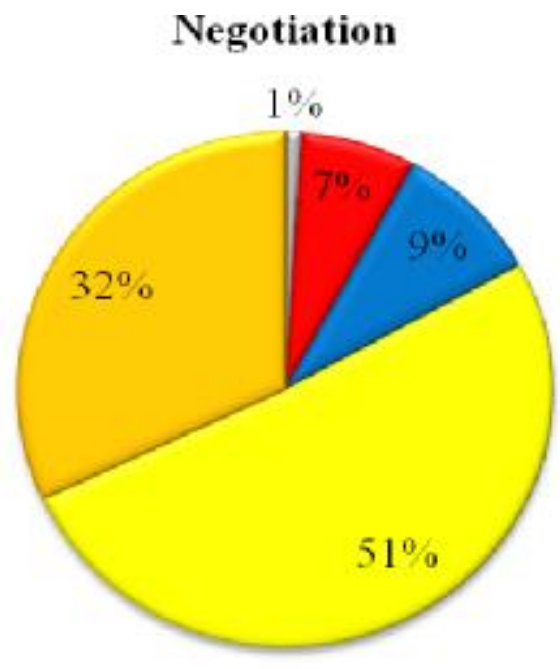

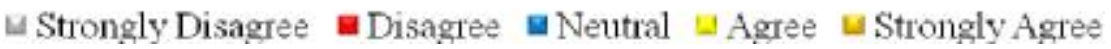

Figure 5 shows that $51 \%$ engineers agreed and $32 \%$ strongly agreed that negotiation is an important aspect of modern workplace communication.

\section{Discussion}

The results of this study reported that oral communication skills play vital role for engineers at workplace. It assists them to perform workplace jobs effectively and efficiently according to employer satisfaction. For oral presentation 39\% engineers agreed and 39\% strongly agreed that oral presentation is a required skill for engineers at workplace. Engineers further identified that employers' value oral presentation skill of engineers and they spend major part of time in oral communication activities at workplace. In addition, they identified that engineers equipped with effective oral presentation skill promote business of organizations. For meetings $54 \%$ engineers agreed and 30\% strongly agreed that oral communication is an important factor to discuss workplace matters during meetings. Engineers identified that engineers equipped with effective oral communication skill dominate whole meetings. Conversely, engineers equipped with poor oral communication skills remain silent during meeting. In addition, they further identified that due to poor oral communication skill engineers fail to present expert opinion during meetings.

For conversation $52 \%$ engineers agreed and 29\% strongly agreed that workplace conversation develop better work relationship among engineers at workplace. Engineers identified that engineers equipped with effective oral communication dominate conversations and poor conversation skill of engineers develop poor image for them at workplace. For discussion 50\% engineers agreed and 34\% strongly agreed that workplace discussions promote better work environment of organizations. Engineers identified that oral communication is an important skill to discuss work related matters with senior engineers. In addition, they identified that engineers equipped with poor oral communication skill do not take part in discussions at workplace. Moreover, due to poor oral communication skill engineers usually fail to convince colleagues during discussions at workplace.

On the other hand, for negotiation $51 \%$ engineers agreed and 32\% strongly agreed that negotiation is an important aspect of modern workplace communication. Engineers identified that engineers equipped with effective oral communication skills bring various financial benefits for organizations. They further identified that engineers equipped with poor oral communication skills damage interests of organization and due to poor oral communication skill engineers usually avoid playing the role of negotiator at workplace.

The findings of this study are consistent with a study conducted by Van Horn (1995) that reported employers

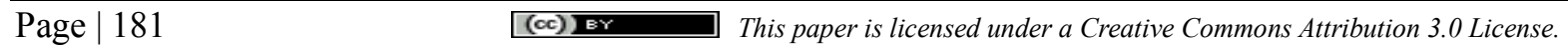




\section{International Journal of Applied Linguistics \& English Literature}

ISSN 2200-3592 (Print), ISSN 2200-3452 (Online)

Vol. 1 No. 5; September 2012 [Special Issue on General Linguistics]

rated oral communication important for workplace jobs. Crosling and Ward (2002) surveyed workplace communication skills for business graduates. The findings of the survey revealed that $84 \%$ employer respondents' indicated that communication usually occurs at workplace. Moreover, Gray (2009) investigated importance of oral communication skills for accountancy graduates in New Zealand. Findings of this study indicated that $91 \%$ of respondents considered oral communication skills as 'very important' at workplace. Additionally, Freihat Saleh et al. (2012) conducted a study on "The Picture of Workplace Oral Communication Skills for ESP Jordanian Business Graduate Employees". The results of this study indicated that $84 \%$ respondents agreed that oral communication often occurs at workplace. The results of these studies support findings of this study on importance of oral communication skills for engineers at workplace.

\section{Conclusion}

This study investigated importance of oral communication for engineers at workplace. The results of this study indicated that oral communication skills such as oral presentation, participation in meeting, conversation, discussion, and negotiation skill play pivotal role for engineers at workplace. This is because oral communication is an important aspect of modern workplace communication and it involves communication with multiple stakeholders such as workers, customers, mangers, employers, and executives of the organization. Truly, engineering is a profession that demands technical and non technical skills of engineers to promote business of organizations at national and international level. Oral communication skills have become better predictors that assist employers to increase workplace productivity of organizations. Thus, employers demand engineering graduates equipped with effective oral communication skills to run business of organization productively. Looking at from this perspective point of view, it is suggested that engineering universities of Pakistan should focus oral communication skills of engineering students to prepare better engineers for the workplace. The ultimate goal of engineering is to train students (Denis Lemaitre et al., 2006) for workplace. Thus, it is concluded that industry and academia should arrange communication skill trainings for engineers and engineering students during study time and following graduation at workplace if they want to promote business of organizations and overcome increasing unemployment in engineering profession of Pakistan.

\section{References}

Arn, J., Kordsmeier, B., \& Gatlin-Watts, R. (2010). A survey of workforce communication skills. Journal of Organizational Culture, Communications and Conflict, 6(1-2), 1.

Bargiela-Chiappini F., \& Harris, S. (1997). Managing Language. Amsterdam: John Benjamins Publishing Company.

Baron, R. A. (1989). Personality and organizational conflict: Effects of type behaviour and self-monitoring. Organizational Behaviour and Human Decision Processes, 44, pp. 281-296.

Bhattacharyya, E., Nordin, S.M. \& Salleh, R. (2009). Internship Students' Workplace Communication Skills: Workplace Practices and University Preparation. Proceedings for the CIEC Conference, Florida, Orlando, USA.

Crosling, G. \& Ward, I. (2002). Oral communication: The workplace needs and uses of business graduate employees. English for Specific Purposes, 21, (1), 41-57.

Dannels, D. P. (2002). Communication across the curriculum and in the disciplines: Speaking in engineering. Communication Education, 51(3), 254-268.

Denis Lemaitre, Raymond Le Prat, Erik De Graaff \& Ludovic Bot (2006). Focusing on competence, European Journal of Engineering Education, 31:01, 45-5

Employers Value Communication and Interpersonal Abilities. (2004, January). Keying In, 14(3), 1-6.

Fernando de Oliveira Carvalho and Felipe Sobral (2001). The importance of communication skills in negotiation: an empirical study. 16 the Annual JOAM Conference Melbourne Australia. Retrieved on 13-7-2012 from Social Science Research Network. http://papers.ssrn.com/so13/papers.cfm...

Gray, E. (2009). Specific oral communication skills desired in new accountancy graduates. Business Communication Quarterly, 73, 40-67, first published on January 28, 2010.

Hafizoah Kassim \& Fatimah Ali. (2010). English communicative events and skills needed at the workplace: 
International Journal of Applied Linguistics \& English Literature

ISSN 2200-3592 (Print), ISSN 2200-3452 (Online)

Vol. 1 No. 5; September 2012 [Special Issue on General Linguistics]

Feedback from the industry. English for Specific Purposes, 29(3), 168-182.

Jaderstrom, S., \& Schoenrock, R. (2008). Teaching the NBEA communication standards. Business Education Forum, 62(4), 25-29.

James, R.F., \& James, M.L. (2004). Teaching career and technical skills in a "mini” business world. Business Education Forum, 59(2), 39-41.

James, M. L., \& Lippe, G. (2005). Graduates agree on the importance of traditional business communication topics. Business Education Forum, 60(2), 34-37.

Hoggatt, J. (2003). Addressing the communication needs of business. Business Education Forum, 58(1), 26-30.

Keane, A. and Gibson, I.S., (1999). Communication trends in engineering firms: implications for undergraduate engineering courses. International Journal of Engineering Education, 15, 2, 115-121 (1999).

Korte, S. Sheppard, and W. Jordan. (2008). A qualitative study of the early work experiences of recent graduates in engineering, in Proceedings of ASEE Annual Conference.

Lehman, C., \& DuFrene, D. (2008). Business communication (15th edition).Cincinnati, OH:

South-Western/Thompson Learning.

Mellinger, W. M. (1992). Talk - as - Work: the Case of Paramedic Calls for Emergency Field Orders. Current Research on Occupations and Professions, 7, $79-109$.

Saleh Freihat, Khalaf Al-Machzoomi (2012). The Picture of Workplace Oral Communication Skills for ESP Jordanian Business Graduate Employees. International Journal of Business, Humanities and Technology, Vol. 2 No. 1; January 2012

Singleton, R. A. Jr., \& Straits, B. C. (2005). Approaches to social research. New York, N.Y.: Oxford University Press.

Sutton, N. (2002) Why can’t we all just get along? Computing Canada, (28)16, 20

Tilli, S., \& Trevelyan, J. P. (2008). Longitudinal Study of Australian Engineering Graduates: Preliminary Results. Paper presented at the American Society for Engineering Education Annual Conference, Pittsburgh.

Van Horn, C. E. (1995). Enhancing the Connection Between Higher Education and the Workplace: A Survey of Employers. Denver, CO: State Higher Education Executive Officers Association.

Woodilla, J. (1998). Workplace Conversations: The Text of Organizing. In D. Grant, T. Keenoy \& C. Oswick (Eds.), Discourse and Organization 31-50. London: Sage.

\section{Authors}

Inayatullah Kakepoto earned Master of Art (Sociology, English Literature) both from Shah Abdul Latif University Khairpur (Sind) Pakistan. His teaching experience is spread more than over a period of decade as Lecturer (English) at Cadet College Petaro (Pakistan Navy), and as Assistant Professor at Quaid-e-Awam University of Engineering Science and Technology Nawabshah (Sind) Pakistan. Currently the researcher is a doctoral student at Universiti Teknologi Malaysia. His research interests include Workplace Communication, Soft Skills, Business Communication, and Engineering Education.

Noor Abidah Mohd. Omar earned her PhD (Management and Modern Language) from Aston United Kingdom. She is currently working as Associate Professor (Language Academy) Universiti Teknologi Malaysia. Her research interests include English Language Syllabus and Curriculum Design, English for Specific Purposes, English for Academic Purposes, Grammar and English language Structures. 